\title{
Development of Indonesian Language Teaching Materials Based on Google Classroom in Primary Schools
}

\author{
Siti Halidjah ${ }^{\text {* }}$, Rio Pranata ${ }^{2}$ (D) \\ ${ }^{1,2}$ Elementary School Teacher Study Program, Universitas Tanjungpura, Pontianak, Indonesia \\ e-mail: halidjah99@gmail.com
}

\section{A R T I CLE IN F O}

Article history:

Received April 10, 2021

Revised April 11, 2021

Accepted May 05, 2021

Available online May 25, 2021

Kata Kunci:

Bahan Ajar, Bahasa Indonesia, Google Classroom

Keywords:

Teaching Materials, Indonesian Language, Google Classroom

\begin{abstract}
A B S T R A K
Perubahan pembelajaran tatap muka menjadi pembelajaran online yang membuat guru kesulitan dalam menciptakan pembelajaran yang baik. Hal ini menyebabkan hasil belajar siswa menjadi rendah karena siswa mengalami kesulitan dalam belajar. Penelitian ini bertujuan untuk mengembangkan bahan ajar berbasis Google Classroom yang sesuai untuk pembelajaran bahasa Indonesia pada tema 3 subtema 1 untuk kelas IV di sekolah dasar. Jenis penelitian ini adalah penelitian pengembangan yang menggunakan model ADDIE. Subjek penelitian yaitu 3 orang ahli dari validator ahli media, validator ahli bahasa, dan desain pembelajaan. Sampel penelitian sebanyak 32 siswa. Metode yang digunakan untuk menganalisis data yaitu observasi, wawancara, dan kuesioner. Instrument yang digunakan dalam mengumpulkan data yaitu kuesioner. Teknik yang digunakan untuk menganalisis data penelitian yaitu analisis deskriptif kualitatif dan kuantitatif. Hasil penelitian yaitu validasi ahli desain menunjukkan angka rata-rata 4,6 yang dikategorikan sangat valid; validasi ahli video pembelajaran menunjukkan rata-rata 4,75 yang juga tergolong sangat valid. Hasil validasi video kajian ahli bahasa dan ahli juga menunjukkan hasil yang sangat valid dengan rerata masing-masing 4,35 dan 4,65. Selain itu, hasil validasi ahli e-book learning dan video pembelajaran diperoleh skor rata-rata 4,6 dan 4,55, dan kedua angka tersebut tergolong sangat valid. Terakhir, penilaian kepraktisan guru terhadap bahan ajar diperoleh rata-rata 3,45 dan tergolong sangat praktis. Dapat disimpulkan bahwa bahan ajar berbasis Google Classroom yang sesuai untuk pembelajaran bahasa Indonesia layak diterapkan dalam proses pembelajaran. implikasi penelitian ini yaitu bahan ajar yang dikembangkan dapat digunakanoleh guru untuk memudahkan siswa dalam belajar Bahasa Indonesia.
\end{abstract}

\section{A B S T R A C T}

The change from face-to-face learning to online learning makes it difficult for teachers to create good learning. This causes student learning outcomes to be low because students have difficulty in learning. This study aims to develop Google Classroom-based teaching materials suitable for learning Indonesian on theme 3 sub-theme 1 for grade IV in elementary schools. This type of research is development research that uses the ADDIE model. The research subjects are 3 experts from media expert validator, linguist validator, and learning design. The research sample was 32 students. The methods used to analyze the data are observation, interviews, and questionnaires. The instrument used in collecting data is a questionnaire. The technique used to analyze the research data is descriptive qualitative and quantitative analysis. The study results, namely the validation of design experts, showed an average number of 4.6, which was categorized as very valid; the expert validation of the learning video shows an average of 4.75 , which is also classified as very valid. The results of video validation studies of linguists and experts also show very valid results with an average of 4.35 and 4.65 , respectively. In addition, the results of expert validation of e-book learning and learning videos obtained an average score of 4.6 and 4.55 , and both numbers are classified as very valid. Finally, the teacher's assessment of the practicality of teaching materials obtained an average of 3.45 and is classified as very practical. It can be concluded that Google Classroom-based teaching materials suitable for learning Indonesian are feasible to be applied in the learning process. This research implies that teachers' teaching materials can be used by teachers to facilitate students in learning Indonesian.

This is an open access article under the CC BY-SA license.

Copyright (C) 2021 by Author. Published by Universitas Pendidikan Ganesha.

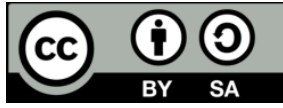

\section{INTRODUCTION}

Thematic learning is integrated learning that emphasizes student involvement in learning activities (Anshory, 2020; Candra, Sulistya, \& Prasetyo, 2018; Kumalasani, 2018; F. Pratama, Firman, \& Neviyarni, 2019). The implementation of integrated thematic learning in grades I, II, III of Elementary School unites various subjects under one theme, such as Citizenship Education, Indonesian Language, Mathematics, and 
Cultural Arts and Crafts, while religion, physical education, and sports are separated from the theme (Putri \& Desyandari, 2019; Sari, Akbar, \& Yuniastuti, 2018; Winaya, 2018). In grades IV, V, VI SD, thematic lessons are a combination of various subjects in one theme such as Citizenship Education, Indonesian Language, Social Sciences, Science, and Cultural Arts and Crafts (Candra et al., 2018; Hidayati, 2016; Izati, Wahyudi, \& Sugiyarti, 2018). The implementation of learning activities is expected to help students to develop their abilities. One of the most essential lessons for elementary school students is Indonesian.

Indonesian language learning emphasizes language competence as a communication tool to convey ideas, thoughts, and opinions (Asna \& Mimi, 2016; Joyo, 2018; Susanti, Sumantri, \& Sudana, 2018). Mastery of language is essential to be understood by students to facilitate mastery of other sciences (Puspitasari, 2018; Rosdiana, Kusmariyatni, \& Widiana, 2013). Accurate and precise use of language is essential for everyone because language is a medium of communication between people around the world (Alias, Manan, Yusof, \& Pandian, 2012; Mohammadi, Moenikia, \& Zahed-Babelan, 2020; Rap \& Blonder, 2017). Learning Indonesian at the State Elementary School and Madrasah Ibitidaiyah levels are directed at developing students' ability to communicate. Accurately and correctly, both in written and oral form (Agathi Dian, Kristiantari, \& Ganing, 2015; Dewi, Kristiantari, \& Ganing, 2019; Irwandi, 2020). There is a fundamental change in the 2013 Curriculum, especially in learning Indonesian, which occurs in determining language units as the basis for learning materials.

The current problem is the change from face-to-face learning to online learning, making it difficult for teachers to create good learning (Ayuni, Marini, Fauziddin, \& Pahrul, 2021; Batubara \& Batubara, 2020; Mamluah \& Maulidi, 2021). This is due to the Covid-19 pandemic. This transition is intended to support government policies in preventing the spread of the virus so that students are required to study from home only (Atmojo \& Nugroho, 2020; Simamora, 2020; Susmiati, 2020). As a result, students' social interactions have only been done with family members at home. This condition encourages students to communicate in a less formal language so that students' excellent and accurate Indonesian language skills are considered very low (Kurniawan, Wijayanti, \& Hawanti, 2020).

Based on observations made at SD Negeri 03 Pontianak Selatan with fourth-grade elementary school teachers, information was obtained that the learning process during the COVID-19 pandemic was still carried out online. The time used for learning activities is short, about 25-30 minutes for 1 hour of lessons, so not all lesson content can be taught directly. This causes students' Indonesian language skills to be low, as evidenced by the daily assessment on Theme 3 material that does not reach the school KKM. In addition, online learning materials prepared by teachers also proved to be less attractive and unclear to students. This information was obtained from a questionnaire given to students via Google Form. The teacher gave many assignments to students after the learning material, which resulted in many students feeling less motivated in doing these assignments. These tasks are ultimately done by other people, such as parents or siblings of students, and not by themselves. The questionnaire findings revealed that students wanted a change in the teaching materials used by the teacher. As many as $74 \%$ of students are interested in learning to use e-books, and $29.6 \%$ of students are interested in learning to use learning videos.

Mastery of language will make it easier for people to communicate effectively to convey ideas, express feelings, and solve various problems (Mohammadi et al., 2020; Paul \& Singh, 2020). As the official language of Indonesia, Indonesian is considered one of the most important languages to master (Hasanah, Nurjaya, \& Astika, 2017; Widayanti, Sutama, \& Wisudariani, 2019). This causes teachers to be prepared for learning carefully to achieve goals according to competency standards, required competencies, and indicators (Boesdorfer, 2015; Riyanti, Suciati, \& Karyanto, 2018; Tsai, Lin, Hong, \& Tai, 2018). The components included in teaching and learning activities are learning objectives, learning methods, media, teaching materials, evaluations, students, and educators (Li, Hwang, Chen, \& Lin, 2021; Partovi \& Razavi, 2019; Sadeghi \& Sadeghi, 2012). Good learning will make it easier for students to understand the learning material.

The solution offered to overcome these problems is developing innovative teaching material that makes it easier for students to learn languages. Digital teaching materials will make it easier for students to learn independently (Irwansyah, Lubab, Farida, \& Ramdhani, 2017b; Liu, Kong, Jiang, \& Li, 2021; Neppala et al., 2018). Interactive modules can also increase students' enthusiasm for learning (Hamdunah, Yunita, Zulkardi, \& Muhafzan, 2016). One popularly used application is Google Classroom (Kurniawati, Santanapurba, \& Kusumawati, 2019; Mahitsa \& Mahardini, 2020). Electronic applications used in learning should have features that can organize and collect student assignments automatically. The various subject matter contained in the teaching materials supports the learning process. Teaching materials also consist of learning materials consisting of knowledge, skills, and attitudes that students must learn to achieve predetermined competency standards (Perdana, Sarwanto, Sukarmin, \& Sujadi, 2017; Rasmawan, 2018). The development of teaching materials is needed according to student needs, curriculum demands, regional characteristics, and learning problem-solving demands (Diantari, Damayanthi, Sugihartini, \& Wirawan, 2018; Herawati \& Muhtadi, 2018). 
Previous research findings stated that interactive modules could help students with learning difficulties (Kimianti \& Prasetyo, 2019; Laili, Ganefri, \& Usmeldi, 2019; Udayana, Wirawan, \& Divayana, 2017). Other research findings also state that interactive modules can improve student learning outcomes (Canboy, Montalvo, Buganza, \& Emmerling, 2016; Hamid, Lee, Taha, Rahim, \& Sharif, 2021). There is no study on developing Indonesian language teaching materials based on Google Classroom in elementary schools. This research aims to develop Indonesian language teaching materials based on Google Classroom in elementary schools. Through the development of these teaching materials, it is hoped that teaching materials will be produced that are suitable for use by students to communicate, convey ideas, provide thoughts and opinions correctly and adequately.

\section{METHOD}

This type of research is development research. The method used in this study is the Research and Development Method which is supported by the ADDIE model, namely analysis, design, development, implementation, and evaluation (Wulandari, Sudatha, \& Simamora, 2020). The development design is presented in Figure 1.

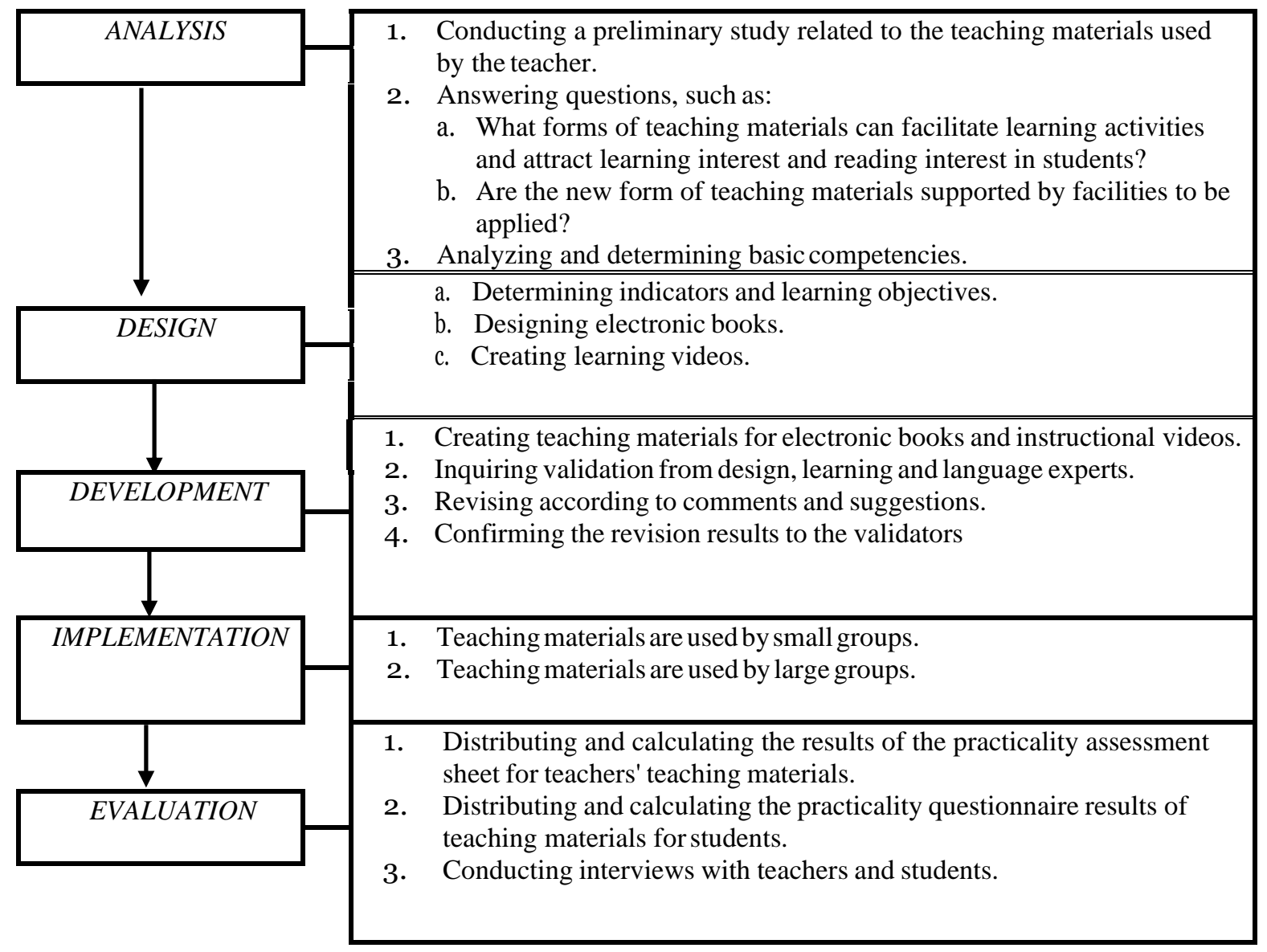

Figure 1. ADDIE Development Model in E-books and Instructional Videos

This research was conducted at SDN 03 Pontianak. The subjects in this study were all fourth-grade students who had studied the learning material for Theme 3. The researcher took a sample of 32 students. The research subjects are three experts from media expert validator, linguist validator, and learning design. The methods used to analyze the data are observation, interviews, and questionnaires. Observations and interviews were conducted to analyze the problems that were happening in the field. Questionnaires were used to collect assessment data given by experts and students. The instrument used in collecting data is a questionnaire. The techniques used to analyze the research data are qualitative descriptive analysis, quantitative, and inferential statistics. This technique is a qualitative descriptive analysis used to process data from the results of trials from experts based on the input provided. The quantitative descriptive analysis technique is used to process data from trials from experts based on the assessment given. Then, the calculation results are transcribed into a table of levels of validity criteria, which can be seen in the table with a range of 0.8 below. 


\section{RESULT AND DISCUSSION}

This study's development of Indonesian language teaching materials uses the ADDIE model for Theme 3 Sub-theme 1 in Class IV SDN 03 South Pontianak. The ADDIE model consists of five stages: Analysis, Design, Development, Implementation, and Evaluation. A brief explanation of these stages is as follows. The first stage is analysis. The analysis is the initial stage for researchers to start product development. In this case, the material is in the form of an electronic book equipped with learning videos. In the analysis stage, interviews with classroom teachers were conducted to achieve these results, then distributed a questionnaire on teachers and students' need for teaching materials via Google Form. From the results of interviews, it was obtained data that indirect learning caused several obstacles, such as the short delivery time of learning materials. Some subject matter is not taught by the teacher directly. Teachers must be able to overcome the problem of short time so that students can learn optimally. In addition, the media for delivering learning materials must also make it easier for teachers to control students. Teachers should make teaching materials that make it easier for students to learn independently because of the limited time to deliver all learning materials. Furthermore, researchers found problems in the teaching materials used by students, especially teaching incomplete materials, making it difficult for students to study independently. Finally, students also need interesting teaching materials both visually and audiovisually. Based on the teacher's information regarding the incompleteness of teaching materials in Indonesian language learning, the researchers then distributed a questionnaire on the needs of teaching materials for students to obtain other information. The researchers found that $70.4 \%$ of students were interested in learning to use e-books, and $29.6 \%$ of students were enthusiastic about learning videos from the questionnaire that students filled out via Google Form.

The second stage designs. At this stage, the activities carried out make attractive designs and complement existing teaching materials so that students are more interested in reading to obtain more information. Researchers' electronic books are considered very interactive, making it easier for students to learn these subjects. At this stage, the researcher made an attractive learning video design to make students more enthusiastic about learning. The subject matter delivered via video is adapted to the subject matter in the electronic book. Learning videos describe the subject matter as a whole and are presented using words that students easily understand. The media design created is presented in Figure 2.

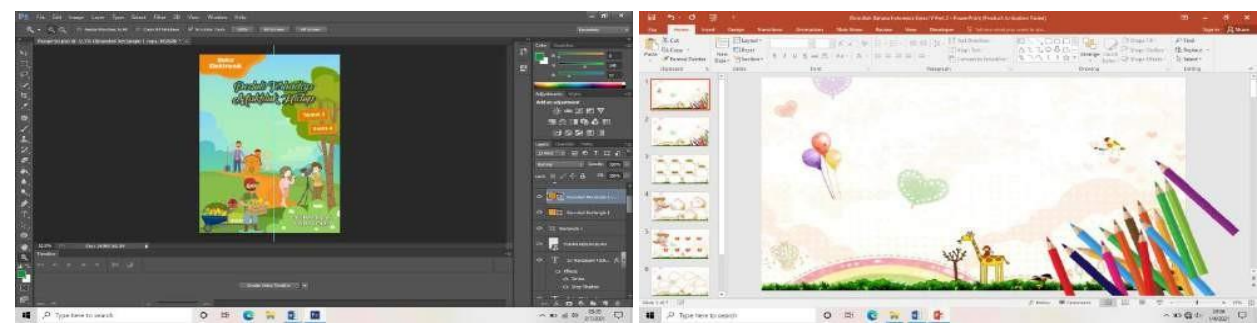

Figure 2. Desifn E-book and Learning video

The third stage is development. At this stage, the development of electronic book drafts and learning videos was carried out. development of electronic books and learning videos adapted to the designs that have been made previously. The results of the development are presented in Figure 3.
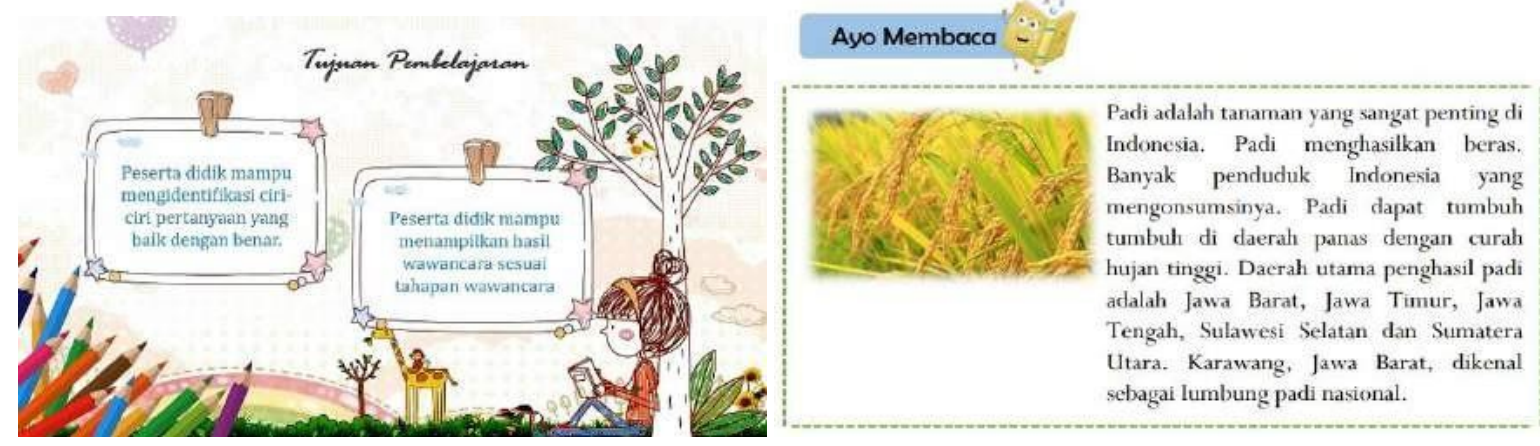

Figure 3. Electronic Teaching Materials developed

After the Electronic Book has been successfully developed, the next step is to test the validity of the media that has been developed. At this stage, the electronic book and learning video draft was assessed by three design, language, and learning experts to carry out the validation process. The validation process was carried out 
twice by design experts, linguists, and learning experts, with the following results.

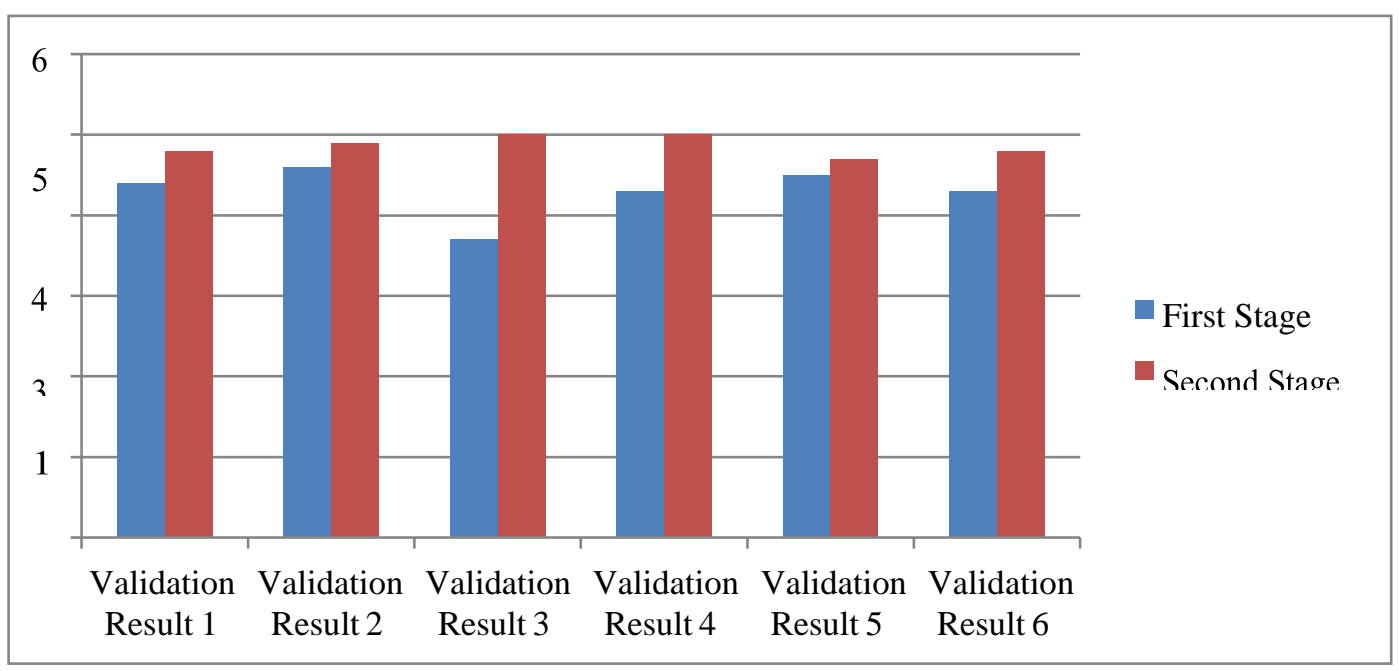

Graph 1. The Experts' Validation Result in First and Second Stage

As can be seen from the graph above, the Validation Results 1-6 are the Validation of e-book design experts, learning video design experts, e-book language experts, learning video experts, e-book learning experts, and expert Validation on learning videos. Design expert validation shows an average score of 4.6, which is categorized as very valid; the expert validation of the learning video shows an average of 4.75 , which is also very valid. The results of video validation studies of linguists and experts also show very valid results with an average of 4.35 and 4.65, respectively. In addition, the results of expert validation of e-book learning and learning videos obtained an average score of 4.6 and 4.55, and both numbers are classified as very valid. Finally, the teacher's assessment of the practicality of teaching materials obtained an average of 3.45 and is classified as very practical. From these results, it can be concluded that the developed media in the form of Electronic Books get very good qualifications so that they are feasible to be applied in the learning process. Some inputs given by experts are that the author must pay attention to the title of the chosen theme and sub-theme so that the cover design can display these two elements, adjust the selection of images with the theme and sub-theme. The author's name should also be written on the cover of the book. Researchers conduct product revisions to produce quality products. The results of the product revision are presented in Figure 4.

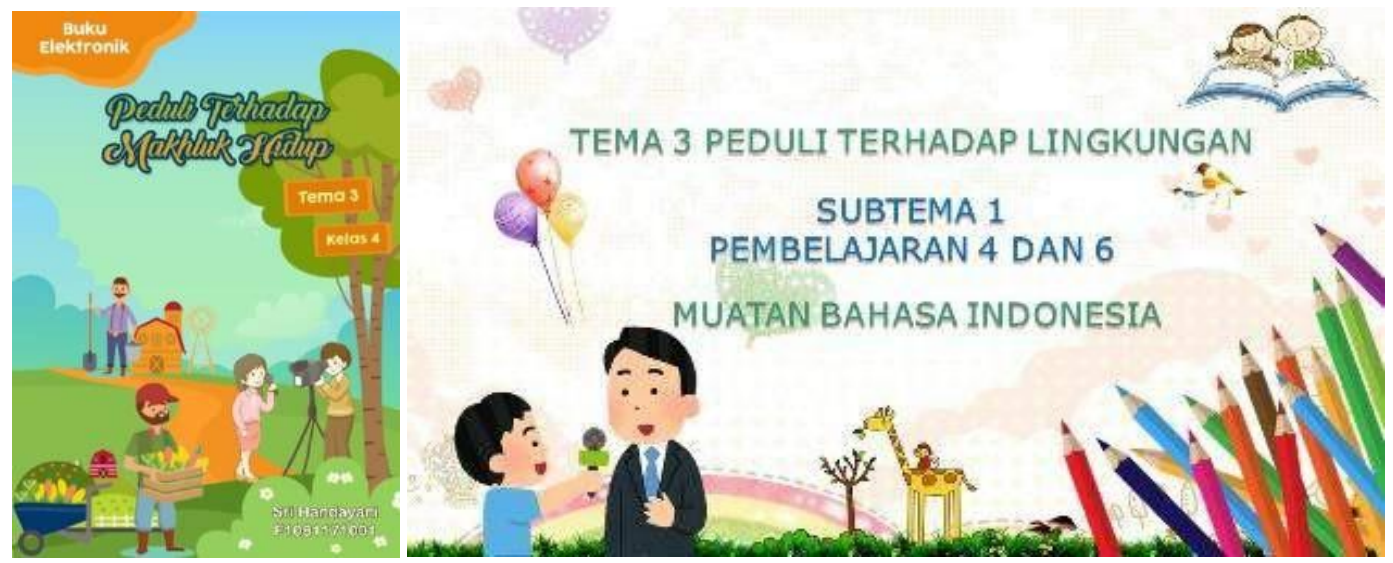

Figure 4. Results of the revised Electronic Teaching Materials developed

Based on the results of data analysis, it can be concluded that the teaching materials in the Indonesian Language class Theme 3 Subtheme 1 Class IV based on Google Classroom are suitable for student learning to get very good qualifications so that they are feasible to apply this is due to several factors. First, the developed electronic teaching materials make it easier for students to learn languages. These electronic teaching materials were developed according to the characteristics of students, making it easier for students to understand the information presented in these teaching materials. Teaching materials adapted to students will make it easier for students to learn (Resita \& Ertikanto, 2018; Seruni, Munawaroh, Kurniadewi, \& Nurjayadi, 2020). The addition 
of examples in the form of pictures or illustrations will make it easier for students to understand the learning material (Boyd, 2019; Irwansyah, Lubab, Farida, \& Ramdhani, 2017a; Komikesari et al., 2020). Good use of language will also make it easier for students to understand learning materials (Mohammadi et al., 2020; Paul \& Singh, 2020).

Second, the electronic teaching materials developed are exciting to increase the enthusiasm of students in learning. Learning materials that are packaged very attractively will increase students' enthusiasm in learning (Linda et al., 2018; Yulando, Sutopo, \& Franklin Chi, 2019). This is because students have a visual learning style so that something interesting for students will be able to increase enthusiasm and motivate students to learn (Nena, Wiyasa, \& Ganing, 2013; D. Pratama, Wardani, \& Akbar, 2018; Zhao \& Wu, 2021). Teachers who prepare learning media or fun learning models will increase students' enthusiasm for learning (Li et al., 2021; Partovi \& Razavi, 2019; Sadeghi \& Sadeghi, 2012). Good learning will make it easier for students to understand the learning material. Digital teaching materials will make it easier for students to learn independently (Irwansyah et al., 2017b; Liu et al., 2021; Neppala et al., 2018). The electronic application used also has practical features to make it easier for students to learn.

The findings of previous studies also stated that E-modules could attract students in learning (Imansari \& Sunaryantiningsih, 2017; Khasana, Parmiti, \& Sudatha, 2018; Kimianti \& Prasetyo, 2019). Other research also states that interactive modules can improve student learning outcomes (Aryawan, Sudatha, \& Sukmana, 2018; Herawati \& Muhtadi, 2018; Irwandani, Latifah, Asyhari, Muzannur, \& Widayanti, 2017). It can be concluded that interactive and engaging modules can facilitate students ' learning. The development of these teaching materials can be further developed to test their effectiveness. This research implies that the developed electronic teaching materials can be used by teachers in learning to facilitate learning, especially in Indonesian subjects.

\section{CONCLUSION}

Teaching materials in the Indonesian Language class Theme 3 Subtheme 1 Class IV based on Google Classroom received very good qualifications from experts. It can be concluded that the teaching materials in the Indonesian class are feasible to be applied in the learning process. It is recommended for teachers to use interactive and exciting teaching materials to help students learn Indonesian so that it will have an impact on increasing student learning outcomes.

\section{REFERENCES}

Agathi Dian, I. A. A., Kristiantari, R. M. G., \& Ganing, N. (2015). Guru Terhadap Hasil Belajar Pengetahuan Bahasa Indonesia ( Keterampilan Membaca ) Tema Cita-Citaku Pada Siswa Kelas IV SD Desa Peguyangan. Mimbar PGSD Undiksha, 3(1). http://dx.doi.org/10.23887/jjpgsd.v3i1.5172.

Alias, A. A., Manan, N. A. A., Yusof, J., \& Pandian, A. (2012). The use of Facebook as Language Learning Strategy (LLS) Training Tool on College Students' LLS use and Academic Writing Performance. Procedia - Social and Behavioral Sciences, 67. https://doi.org/10.1016/j.sbspro.2012.11.305.

Anshory, I. (2020). Pembelajaran Tematik Integratif Pada Kurikulum 2013 di Kelas Rendah SD Muhammadiyah 07 Wajak. JINoP (Jurnal Inovasi Pembelajaran), 4(1), 3546. https://doi.org/10.22219/jinop.v4i1.4936.

Aryawan, Sudatha, \& Sukmana. (2018). Pengembangan E-Modul Interaktif Mata Pelajaran IPS Di Smp Negeri 1 Singaraja. Jurnal Edutech Undiksha, 6(2), 180-191. http://dx.doi.org/10.23887/jeu.v6i2.20290.

Asna, \& Mimi. (2016). Peningkatan Hasil dan Kemampuan Membaca Intensif Siswa Kelas IV pada Pembelajaran Bahasa Indonesia dengan Model Pembelajaran Word Square di SD Negeri 27 Batang Anai. Jurnal Konseling Dan Pendidikan, 4(2), 74 - 78. https://doi.org/10.29210/166\%y.

Atmojo, A. E. P., \& Nugroho, A. (2020). EFL classes must go online! Teaching activities and challenges during COVID-19 pandemic in Indonesia. Register Journal, 13(1), 49-76. https://doi.org/10.18326/rgt.v13i1.49-76.

Ayuni, D., Marini, T., Fauziddin, M., \& Pahrul, Y. (2021). Kesiapan Guru TK Menghadapi Pembelajaran Daring Masa Pandemi Covid-19. Jurnal Obsesi: Jurnal Pendidikan Anak Usia Dini, 5(1). https://doi.org/10.31004/obsesi.v5i1.579.

Batubara, H. H., \& Batubara, D. S. (2020). Penggunaan Video Tutorial untuk Mendukung Pembelajaran Daring di Masa Pandemi Virus Corona. Jurnal Madrasah Ibtidaiyah, 5(2), 78-84. http://dx.doi.org/10. 31602/muallimuna.v5i2.2950.

Boesdorfer, S. B. (2015). Growing Teachers and Improving Chemistry Learning: How Best Practices in Chemistry Teacher Education Can Enhance Chemistry Education. ACS Symposium Series, 1335. https://doi.org/10.1021/bk-2019-1335.ch001.

Boyd, L. (2019). Using Technology-Enabled Learning Networks to Drive Module Improvements in the UK 
OpenUniversity. Journal of Interactive Media in Education, 2019(1), 1-7. https://doi.org/10.5334/jime.529.

Canboy, B., Montalvo, A., Buganza, M. C., \& Emmerling, R. J. (2016). 'Module 9': a new course to help students develop interdisciplinary projects using the framework of experiential learning theory. Innovations in Education and Teaching International, 53(4), 445-457. https://doi.org/10.1080/14703297.2014.975150.

Candra, I., Sulistya, N., \& Prasetyo, T. (2018). Pengembangan Instrumen Sikap Sosial Tematik Siswa SD Kelas IV. Jurnal Ilmiah Sekolah Dasar Undiksha, 2(4). http://dx.doi.org/10.23887/jisd.v2i4.16167.

Dewi, N. N. K., Kristiantari, M. . R., \& Ganing, N. N. (2019). Pengaruh Model Pembelajaran Picture And Picture Berbantuan Media Visual Terhadap Keterampilan Menulis Bahasa Indonesia. Journal of Education Technology, 3(4). http://dx.doi.org/10.23887/jet.v3i4.22364.

Diantari, Damayanthi, Sugihartini, \& Wirawan. (2018). Pengembangan E-modul berbasis Mastery Learning untuk Mata Pelajaran KKPI Kelas XI. Jurnal Nasional Pendidikan Teknik Informatika (Janapati), 7(1), 33-48. http://dx.doi.org/10.23887/janapati.v7i1.12166.

Hamdunah, Yunita, A., Zulkardi, \& Muhafzan. (2016). Development a Constructivist Module and Web on Circle and Sphere Material with Wingeom Software. Journal on Mathematics Education, 7(2), 109116. https://doi.org/10.22342/jme.7.2.3536.109-116.

Hamid, S. N. M., Lee, T. T., Taha, H., Rahim, N. A., \& Sharif, A. M. (2021). E-Content Module For Chemistry Massive Open Online Course (Mooc): Development And Students' Perceptions. Journal of Technology and Science Education, 11(1), 67-92. https://doi.org/10.3926/jotse.1074.

Hasanah, Nurjaya, \& Astika. (2017). Pengintegrasian Sikap Spiritual dan Sikap Sosial dalam Pembelajaran Teks Ulasan Film/Drama dalam Pembelajaran Teks Ulasan Film/Drama di Kelas XI MIPA SMA Negeri 3 Singaraja. Jurnal Pendidikan Bahasa Dan Sastra Indonesia Undiksha, 7(2). http://dx.doi.org/10.23887/jjpbs.v7i2.11579.

Herawati, N. S., \& Muhtadi, A. (2018). Pengembangan Modul Elektronik (E-Modul) Interaktif Pada Mata Pelajaran Kimia kelas XI SMA. Jurnal Inovasi Teknologi Pendidikan, 5(2), 180-191. https://doi.org/10.21831/jitp.v5i2.15424.

Hidayati, A. (2016). Merangsang Pertumbuhan Dan Perkembangan Anak Dengan Pembelajaran Tematik Terpadu. Sawwa: Jurnal Studi Gender, 12(1). https://Doi.Org/10.21580/Sa.V12i1.1473.

Imansari, N., \& Sunaryantiningsih, I. (2017). Pengaruh Penggunaan E-Modul Interaktif Terhadap Hasil Belajar Mahasiswa Pada Materi Kesehatan dan Keselamatan Kerja. VOLT : Jurnal Ilmiah Pendidikan Teknik Elektro, 2(1), 11-16. http://dx.doi.org/10.30870/volt.v2i1.1478.

Irwandani, I., Latifah, S., Asyhari, A., Muzannur, M., \& Widayanti, W. (2017). Modul Digital Interaktif Berbasis Articulate Studio'13: Pengembangan pada Materi Gerak Melingkar Kelas X. Jurnal Ilmiah Pendidikan Fisika Al-Biruni, 6(2). https://doi.org/10.24042/jipfalbiruni.v6i2.1862.

Irwandi. (2020). Penggunaan Media Audio Visual Dalam Peningkatan Hasil Belajar Materi Rukun Iman Pada Siswa Kelas I SD Negeri 49 Kota Banda Aceh. Pionir Jurnal Pendidikan, 9(1), 25-44. http://dx.doi.org/10.22373/pjp.v7i1.3321

Irwansyah, F. S., Lubab, I., Farida, I., \& Ramdhani, M. A. (2017a). Designing Interactive Electronic Module in Chemistry Lessons. Journal of Physics: Conference Series, 895(1). https://doi.org/10.1088/17426596/895/1/012009

Irwansyah, Lubab, Farida, \& Ramdhani. (2017b). Designing Interactive Electronic Module in Chemistry Lessons F S. International Conference on Mathematics and Science Education (ICMScE), 895(1), 1-7. https://doi.org/10.1088/1742-6596/895/1/012009.

Izati, Wahyudi, \& Sugiyarti, M. (2018). Project Based Learning Berbasis Literasi untuk Meningkatkan Hasil Belajar Tematik. Jurnal Pendidikan, 3(9), 1122-1127. http://dx.doi.org/10.17977/jptpp.v3i9.11508.

Joyo, A. (2018). Gerakan Literasi Dalam Pembelajaran Bahasa Indonesia Berbasis Kearifan Lokal Menuju Siswa Berkarakter. Jurnal Kajian Bahasa, Sastra Dan Pengajaran (KIBASP), $1(2)$. https://doi.org/10.31539/kibasp.v1i2.193.

Khasana, I. N., Parmiti, D. P., \& Sudatha, I. G. W. (2018). Pengembangan Media Monopoli Dengan Model Hannafin Dan Peck Mata Pelajaran Ips Di Sd Mutiara Singaraja. Jurnal Jurusan Teknologi Pendidikan, 6(2), 205-214. http://dx.doi.org/10.23887/jeu.v6i2.20292.

Kimianti, F., \& Prasetyo, Z. K. (2019). Pengembangan E-Modul Ipa Berbasis Problem Based Learning Untuk Meningkatkan Literasi Sains Siswa. Kwangsan: Jurnal Teknologi Pendidikan, 7(2), 91. https://doi.org/10.31800/jtp.kw.v7n2.p91--103.

Komikesari, H., Mutoharoh, M., Dewi, P. S., Utami, G. N., Anggraini, W., \& Himmah, E. F. (2020). Development of e-module using flip pdf professional on temperature and heat material. Journal of Physics: Conference Series, 1572(1). https://doi.org/10.1088/1742-6596/1572/1/012017.

Kumalasani, M. P. (2018). Kepraktisan Penggunaan Multimedia Interaktif Pada Pembelajaran Tematik Kelas IV 
SD. Jurnal Bidang Pendidikan Dasar, 2(1). https://doi.org/https://doi.org/10.21067/jbpd.v2i1A.2345.

Kurniawan, Wijayanti, \& Hawanti. (2020). Problematika Dan Strategi Dalam Pembelajaran Bahasa Indonesia Di Kelas Rendah Sekolah Dasar. JRPD: Jurnal Riset Pendidikan Dasar, 1(1). http://dx.doi.org/10.30595/.v1i1.7933.

Kurniawati, M., Santanapurba, H., \& Kusumawati, E. (2019). Penerapan Blended Learning Menggunakan Model Flipped Classroom Berbantuan Google Classroom Dalam Pembelajaran Matematika SMP. Jurnal Pendidikan Matematika, 7(1), 8-19. http://dx.doi.org/10.20527/edumat.v7i1.6827.

Laili, Ganefri, \& Usmeldi. (2019). Efektivitas Pengembangan E-Modul Project Based Learning pada Mata Pelajaran Instalasi Motor Listrik. Jurnal Ilmiah Pendidikan Dan Pembelajaran, 3(3). http://dx.doi.org/10.23887/jipp.v3i3.21840. 306-309.

Li, F.-Y., Hwang, G.-J., Chen, P.-Y., \& Lin, Y.-J. (2021). Effects of a concept mapping-based two-tier test strategy on students' digital game-based learning performances and behavioral patterns. Computers \& Education, 24. https://doi.org/https://doi.org/10.1016/j.compedu.2021.104293.

Linda, R., S, I. S., Putra, T. P., Studi, P., Kimia, P., Pendidikan, J., ... Riau, U. (2018). Interactive E-Module Development through Chemistry Magazine on Kvisoft Flipbook Maker Application for Chemistry Learning in Second Semester at Second Grade Senior High School. 2(September), 21-25. https://doi.org/10.17509/jsl.v2i1.12933.

Liu, X., Kong, J., Jiang, M., \& Li, S. (2021). Interactive information module for person re-identification. Journal of Visual Communication and Image Representation, 75. https://doi.org/10.1016/j.jvcir.2021.103033.

Mahitsa, M., \& Mahardini, A. (2020). Analisis Situasi Penggunaan Google Classroom pada Pembelajaran Daring Fisika. Jurnal Pendidikan FIsika, VIII(2), 215-224. http://dx.doi.org/10.24127/jpf.v8i2.3102 analisis.

Mamluah, S. K., \& Maulidi, A. (2021). Pembelajaran Jarak Jauh (PJJ) di Masa Pandemi COVID-19 di Sekolah Dasar. Jurnal Basicedu, 5(2). https://doi.org/10.31004/basicedu.v5i2.800.

Mohammadi, M., Moenikia, M., \& Zahed-Babelan, A. (2020). The role of advance organizer on English language learning as a second language. Procedia - Social and Behavioral Sciences, 2(2). https://doi.org/10.1016/j.sbspro.2010.03.747.

Nena, Wiyasa, I. K. N., \& Ganing, N. N. (2013). Pendekatan Pembelajaran Somatic Auditory Visual And Intellectual (Savi) Berpengaruh Terhadap Hasil Belajar Ipa Siswa Kelas IV SD No.1 Kuta. Mimbar PGSD Undiksha, 1(1). http://dx.doi.org/10.23887/jjpgsd.v1i1.1553.

Neppala, P., Sherer, M. V., Larson, G., Bryant, A. K., Panjwani, N., Murphy, J. D., \& Gillespie, E. F. (2018). An Interactive Contouring Module Improves Engagement and Interest in Radiation Oncology Among Preclinical Medical Students: Results of a Randomized Trial. Practical Radiation Oncology, 8(4), e190-e198. https://doi.org/10.1016/j.prro.2018.01.001.

Partovi, T., \& Razavi, M. R. (2019). The effect of game-based learning on academic achievement motivation of elementary school studentsNo Title. Learning and Motivation, 68. https://doi.org/10.1016/j.lmot.2019.101592.

Paul, R., \& Singh, A. (2020). Does early childhood adversities affect physical, cognitive and language development in indian children? Evidence from a panel study. SSM - Population Health, 12(August), 100693. https://doi.org/10.1016/j.ssmph.2020.100693.

Perdana, Sarwanto, Sukarmin, \& Sujadi. (2017). Development of E-Module Combining Science Process Skills And Dynamics Motion Material To Increasing Critical Thinking Skills And Improve Student Learning Motivation Senior High School. International Journal of Science and Applied Science, 1(1), 45-54. https://doi.org/10.20961/ijsascs.v1i1.5112.

Pratama, D., Wardani, W. G. W., \& Akbar, T. (2018). The Visual Elements Strength in Visual Novel Game Development as the Main Appeal. MUDRA: Jurnal Seni Budaya, 3(3). https://doi.org/10.31091/mudra.v33i3.455.

Pratama, F., Firman, \& Neviyarni. (2019). Pengaruh Motivasi Belajar IPA Siswa Terhadap Hasil Belajar Di Sekolah Dasar Negeri 01. Jurnal Ilmu Pendidikan, 1(3), 280-286. https://doi.org/10.31004/edukatif.v1i3.63.

Puspitasari. (2018). Metode Pembelajaran Bermain Peran Pada Pembelajaran Bahasa Indonesia. Jurnal Cakrawala Pendas, I(1), 55-64. http://dx.doi.org/10.31949/jcp.v1i1.347.

Putri, E. N. D., \& Desyandari. (2019). Penggunaan Media Lagu Dalam Pembelajaran Tematik di Sekolah Dasar. Jurnal Ilmu Pendidikan, 1(3), 233-236. https://doi.org/10.31004/edukatif.v1i3.52.

Rap, S., \& Blonder, R. (2017). Thou shall not try to speak in the Facebook language: Students' perspectives regarding using Facebook for chemistry learning. Computers \& Education, 114. https://doi.org/10.1016/j.compedu.2017.06.014.

Rasmawan. (2018). Development of Chemistry Module for Junior High School Based on Inquiry Accompanied by Performance-Based Assessment. Jurnal Pendidikan Indonesia, 7(2), 111-119. 
https://doi.org/10.23887/jpi-undiksha.v7i2.10617.

Resita, I., \& Ertikanto, C. (2018). Designing electronic module based on learning content development system in fostering students' multi representation skills. Journal of Physics: Conference Series, 1022(1), 012025. https://doi.org/10.1088/1742-6596/1022/1/012025.

Riyanti, H., Suciati, S., \& Karyanto, P. (2018). The Effectiveness Of Generative Learning Model To Enhance Students' Logical-Thinking Ability In Science Learning. Edusains, 10(2). https://doi.org/10.15408/es.v10i2.9044.

Rosdiana, Kusmariyatni, \& Widiana. (2013). Pengaruh Model Pembelajaran Kooperatif Tipe Paired Storytelling Berbantuan Media Audio Visual Terhadap Keterampilan Menyimak Bahasa Indonesia Siswa Kelas V SD. Mimbar PGSD Undiksha, 1(1). http://dx.doi.org/10.23887/jjpgsd.v1i1.826.

Sadeghi, A., \& Sadeghi, A. (2012). The relevance of Mastery Learning (ML) in Teaching of English (Case Study of the University of Guilan, Iran). Creative Education, 3(1). http://dx.doi.org/10.4236/ce.2012.31007.

Sari, Akbar, \& Yuniastuti. (2018). Penerapan Pembelajaran Tematik Terpadu di Sekolah Dasar. Jurnal Pendidikan, 3(12), 1572—1582. http://dx.doi.org/10.17977/jptpp.v3i12.11796.

Seruni, R., Munawaroh, S., Kurniadewi, F., \& Nurjayadi, M. (2020). Implementation of e-module flip PDF professional to improve students' critical thinking skills through problem based learning. Journal of Physics: Conference Series, 1521(4), 1-6. https://doi.org/10.1088/1742-6596/1521/4/042085.

Simamora, R. M. (2020). The Challenges of Online Learning during the COVID-19 Pandemic: An Essay Analysis of Performing Arts Education Students. Studies in Learning and Teaching, 1(2), 86-103. https://doi.org/10.46627/silet.v1i2.38.

Susanti, Sumantri, M., \& Sudana, D. N. (2018). Pengaruh Model Pembelajaran Word Square Berbantuan Cerita Rakyat Terhadap Hasil Belajar Bahasa Indonesia. MIMBAR PGSD Undiksha, 6(3), 169-175. http://dx.doi.org/10.23887/jjpgsd.v6i3.21094.

Susmiati, E. (2020). Meningkatkan Motivasi Belajar Bahasa Indonesia Melalui Penerapan Model Discovery Learning dan Media Video Dalam Kondisi Pandemi Covide-19 bagi Siswa SMPN 2 Gangga. Jurnal Penelitian Dan Pengembangan Pendidikan, 7(3). https://doi.org/10.33394/jp.v7i3.2732.

Tsai, Y., Lin, C., Hong, J., \& Tai, K. (2018). The effects of metacognition on online learning interest and continuance to learn with MOOCs. Computers \& Education, 121. https://doi.org/10.1016/j.compedu.2018.02.011.

Udayana, Wirawan, \& Divayana. (2017). Pengembangan E-modul pada mata pelajaran pemrograman berorientasi objek dengan model pembelajaran Problem Based Learning Kelas VIII rekayasa perangkat lunak. Jurnal Nasional Pendidikan Teknik Informatika (Janapati), 6(2), 128-139. http://dx.doi.org/10.23887/janapati.v6i2.9373.

Widayanti, Sutama, \& Wisudariani. (2019). Pengaruh Penerapan Model Pembelajaran Kooperatif Tipe Problem Posing Terhadap Hasil Belajar Menulis Cerita Fabel Pada Siswa Kelas VII SMP Negeri 2 Sawan Tahun Pelajaran 2018/2019. Jurnal Pendidikan Bahasa Dan Sastra Indonesia Undiksha, 9(1). http://dx.doi.org/10.23887/jjpbs.v9i1.20268.

Winaya, A. I. M. (2018). Efektivitas Implementasi Model Pembelajaran Tematik Berbasis Tekhnohumanistik dalam Pengembangan Nilai-Nilai Karakter pada Peserta didik SD Dwijendra Denpasar. Jurnal Ilmiah Ilmu Sosial, 4(2). http://dx.doi.org/10.23887/jiis.v4i2.16524.

Wulandari, Sudatha, \& Simamora. (2020). Pengembangan Pembelajaran Blended Pada Mata Kuliah Ahara Yoga Semester II di IHDN Denpasar. Jurnal Edutech Undiksha, 8(1), 1-15. http://dx.doi.org/10.23887/jeu.v8i1.26459.

Yulando, S., Sutopo, S., \& Franklin Chi, T. (2019). Electronic Module Design and Development: An Interactive Learning. American Journal of Educational Research, 7(10), 694-698. https://doi.org/10.12691/education-7-10-4.

Zhao, Y., \& Wu, X. (2021). Impact of visual processing skills on reading ability in Chinese deaf children. Research in Developmental Disabilities, 113. https://doi.org/10.1016/j.ridd.2021.103953. 